University of Nebraska - Lincoln

DigitalCommons@University of Nebraska - Lincoln

Agronomy \& Horticulture -- Faculty Publications

Agronomy and Horticulture Department

Spring 2003

Development of a Procedure for Sustainable in Situ Aquifer

Denitrification

Imtiyaz A. Khan

University of Nebraska-Lincoln

Roy F. Spalding

University of Nebraska-Lincoln, rspalding1@unl.edu

Follow this and additional works at: https://digitalcommons.unl.edu/agronomyfacpub

Part of the Plant Sciences Commons

Khan, Imtiyaz A. and Spalding, Roy F., "Development of a Procedure for Sustainable in Situ Aquifer Denitrification" (2003). Agronomy \& Horticulture -- Faculty Publications. 676.

https://digitalcommons.unl.edu/agronomyfacpub/676

This Article is brought to you for free and open access by the Agronomy and Horticulture Department at DigitalCommons@University of Nebraska - Lincoln. It has been accepted for inclusion in Agronomy \& Horticulture -Faculty Publications by an authorized administrator of DigitalCommons@University of Nebraska - Lincoln. 


\title{
Development of a Procedure for Sustainable in Situ Aquifer Denitrification
}

\author{
Imtiyaz A. Khan and Roy F. Spalding \\ Department of Agronomy and Horticulture, University of Nebraska-Lincoln.
}

\begin{abstract}
Denitrification experiments have provided data showing the pitfalls and successes in developing a sustainable injection/extraction system in a sand and gravel aquifer. Experiments increase in complexity from continuous injection at one well to automated-pulsed eight well injections. In both continuous and pulsed injection of organic carbon, $40 \mathrm{mg} \mathrm{NO}_{3} \mathrm{~N} \mathrm{I}^{-1}$ was reduced below the detection limit of $<0.1 \mathrm{mg} \mathrm{NO}_{3} \mathrm{~N}^{-1}$ in the denitrification zones. Under continuous injection, accumulation of bacterial exudates in the vicinity of the injection well resulted in injection well clogging within ten days. Periodic cleaning of the injection well and the adjacent gravel matrix was accomplished by using a tool developed to circulate a cleaning solution composed of 5 percent $\mathrm{H}_{2} \mathrm{O}_{2}$ and 0.02 percent $\mathrm{NaOCl}$; but, biofouling could not be eliminated. In the later experiments, acetate became the carbon amendment because ethanol promoted more biomass development. A specialized pulse injection procedure was developed to separate nitrate from acetate- $C$ and was successful in alleviating the proliferation of bacterial exudates without affecting the performance of the denitrification system. Using pulsed injection, a maximum of 72 percent nitrate reduction was accomplished in the extraction well water, and denitrification was sustained for three months without clogging.
\end{abstract}

\section{INTRODUCTION}

Nitrate is the most pervasive contaminant in groundwater in the United States and throughout the world. In Nebraska, more than 85 percent of the population relies on groundwater for drinking water and more than 20 percent of the domestic wells have nitrate concentrations that exceed the drinking water standard (Spalding \& Exner, 1993). In drinking water, nitrate is reported to cause methemoglobinemia or blue-baby syndrome (Walton, 1951) in infants and bladder cancer in women (Weyer et al., 2001). Many rural communities have wells that exceed the maximum contaminant level (MCL) of $10 \mathrm{mg} \mathrm{NO}_{3^{-}} \mathrm{N}^{-1}$ and find available above-ground treatment alternatives economically prohibitive. Above-ground physical/chemical processes such as ion exchange, reverse osmosis, and electrodialysis do not detoxify nitrate, are very expensive, and generate hazardous brine waste that must be disposed off in a secure landfill at additional cost (Rogalla et al., 1991; Bouwer \& Crowe, 1982). Biodenitrification is the only process that can specifically target nitrate and convert this anion to innocuous end product.

\section{IN SITU DENITRIFICATION}

Enhanced in situ biodenitrification (EISBD) is an emerging technology that offers a cost-effective and environmental friendly solution to the nitrate contamination 
problem (ITRC, 200o). In this study, in situ injection relies on a daisy well system, which constitutes a series of injection wells arranged in a circular pattern around the contaminated well (extraction well) to deliver the needed carbon substrate directly into the nitrate-contaminated zone; whereas the remediated water will be captured by the extraction well. Simultaneous extraction and injection in this configuration creates a pattern of groundwater flow radiating from higher water levels at the injection wells to lower levels created by drawdown at the extraction well. During operation, the water table assumes a configuration that is depicted as being similar to the petals of a daisy flower. When sufficient organic substrate is injected into the groundwater, endemic nitrate degrading microbes (denitrifiers) proliferate in the denitrified zones (DNZ) and enzymatically reduce nitrate to harmless nitrogen gas as follows:

$$
5 \mathrm{C}+4 \mathrm{NO}_{3^{-}}+2 \mathrm{H}_{2} \mathrm{O} \rightarrow 2 \mathrm{~N}_{2}+4 \mathrm{HCO}_{3^{-}}+\mathrm{CO}_{2}
$$

Attempts at in situ denitrification have been reported throughout the world with various degrees of success ( McMahon et al., 1998; Nuttall, 1997; Hammon \& Fustec, 1991; Kruithof et al., 1985; Janda et al., 1988; Mercado et al., 1988; Braester \& Martinell, 1988; Chalupa, 1985). Nitrate removal rates varied from as little as 10 percent to almost complete removal. However, in most cases the performance of the denitrification process was impaired by the excessive and rapid biomass growth in the immediate vicinity of the injection well. This resulted in clogging and rendered the injection well inoperable. Recent researches (Semprini et al., 1988; Shouche et al., 1993; Peyton, 1996; Khan, 2000) suggested that a nutrient pulsing technique minimized biofouling at the injection well. However, these studies were limited to computer simulations or small-scale saturated sand box applications. The goal of this field study is to develop a sustainable method in which biofouling is controlled and nitrate concentrations are lowered to below MCL.

\section{SITE DESCRIPTION AND HYDROGEOLOGY}

The study site is located five miles northwest of Central City in Merrick County, Nebraska (Exhibit 1). Since the 1970s, Merrick County groundwater has been known to have high and consistent nitrate concentrations (Spalding et al., 1978). The $\delta{ }_{15} \mathrm{~N}$ values of nitrate in groundwater at this site confirmed that the primary nitrate source is commercial fertilizer leachates (Bates \& Spalding, 1998).

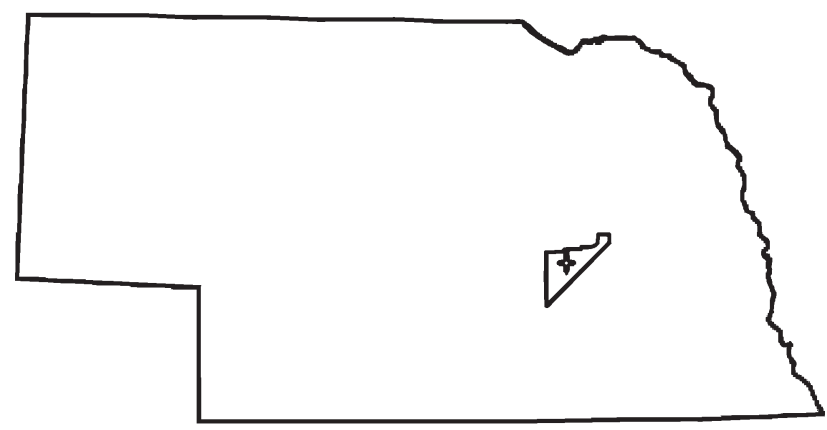

Exhibit 1. Project site in Merrick County, Nebraska. 
The aquifer is unconfined and composed of fluvial sand and gravel material deposited in the Quaternary (Pleistocene) (Spalding et al., 1978). Particle size analysis of the aquifer matrix collected from denitrification zone (depth 36-48 feet) with a Geoprobe $^{\mathrm{TM}}$ showed that aquifer material is composed of 29 percent gravel, 44 percent coarse sand, 26 percent medium to fine sand, and 1 percent silts plus clays. The sand has an effective diameter $\left(\mathrm{d}_{10}\right)$ of $0.25 \mathrm{~mm}$ and a uniformity coefficient $(\mathrm{U}=$ $\left.\mathrm{d}_{60} / \mathrm{d}_{10}\right)$ of 6 , which specifies the non-uniformity in the grain size of aquifer material.

The depth to groundwater at the study area is $\sim 8$ feet and the saturated thickness of aquifer is about 40 feet. The direction of regional groundwater flow is 100 east-northeast. Average hydraulic conductivity of the aquifer as determined from the pump test using the Moench solution (1993) for partially penetrating wells was $290 \mathrm{ft} \mathrm{d}^{-1}$. A forced gradient tracer test along with simulations using particle tracking analyses Modflow (McDonald \& Harbaugh, 1988) and Modpath(Pollock, 1994) estimated a minimum residence time for the injectate of 1.75 days. The average residence time was ten days, although it varied depending on the injection well location and trajectory of the path line (Khan, 2000). Previous microcosm study (Bates \& Spalding, 1998) had shown that this residence time is more than sufficient for complete denitrification. The size of the capture zones developed by the model indicated that eight injection wells were required to denitrify the majority of area defined within the daisy circle.

Biodenitrification is dependent on introduction of enhanced organic carbon to deplete the dissolved oxygen and stimulate the denitrifiers. The aquifer is characterized as being well-suited for in situ remediation because it has high hydraulic conductivity, is shallow, has a suitable groundwater chemistry, and contains indigenous denitrifying bacteria (Bates \& Spalding, 1998).

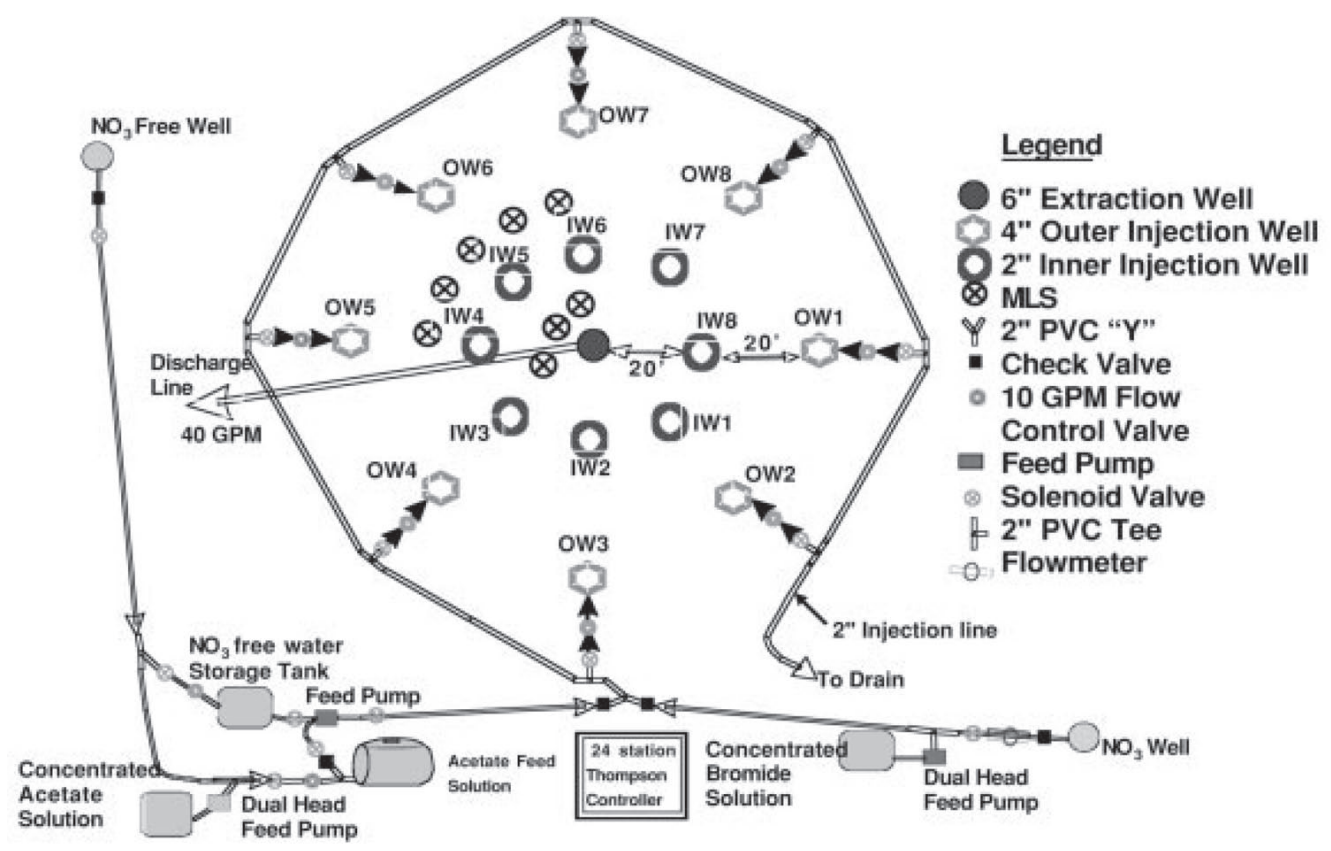

Exhibit 2. Design of daisy system. 


\section{EXPERIMENTAL DESIGN}

The daisy well system consisted of eight 4-inch diameter outer perimeter wells, eight 2-inch diameter inner perimeter wells, and one 6-inch diameter centrally located extraction well (Exhibit 2). The outer and inner perimeter wells are located at a distance of 40 feet and 20 feet away from the extraction well, respectively.

Boreholes were drilled with hollow stem-augers and cased with schedule 40 PVC to completion depths of 48 feet (Exhibit 3). Each casing was constructed with a 10foot-long screened section, which was slotted with a o.o10-inch opening and positioned from 38 feet to 48 feet below the ground surface. These partially penetrating wells were designed to denitrify only the deeper one-quarter of the aquifer. The outer injection wells' screens were modified with 20-foot screen (o.020-inch slot size) to optimize extracted denitrified water in experiments during 2000 . The annular space between the borehole and the screened section of the wells was packed with screened-clean silica sand (0.35-0.38 inch). The 2-foot annular space above the screen was sealed with bentonite and the remaining annular space to the land surface was cement grouted. The well casing was sealed at the top and encased in a steel cover, which was padlocked when the wells were not operational for an extended period of time. The total cost for well installation was about \$50,000 and another \$25,00o was used for packers, valves, pumps, and controller.

The outer perimeter wells were utilized for organic carbon injection while inner perimeter wells intermittently received oxidant hydrogen peroxide $\left(\mathrm{H}_{2} \mathrm{O}_{2}\right)$ to oxidize residual carbon, nitrite, and microbial exudates. The extraction well was continuously pumped with a 1 horsepower (hp) submersible pump at a rates designed to radially capture the denitrified water (Exhibit 3). Multilevel sampler (MLS) wells

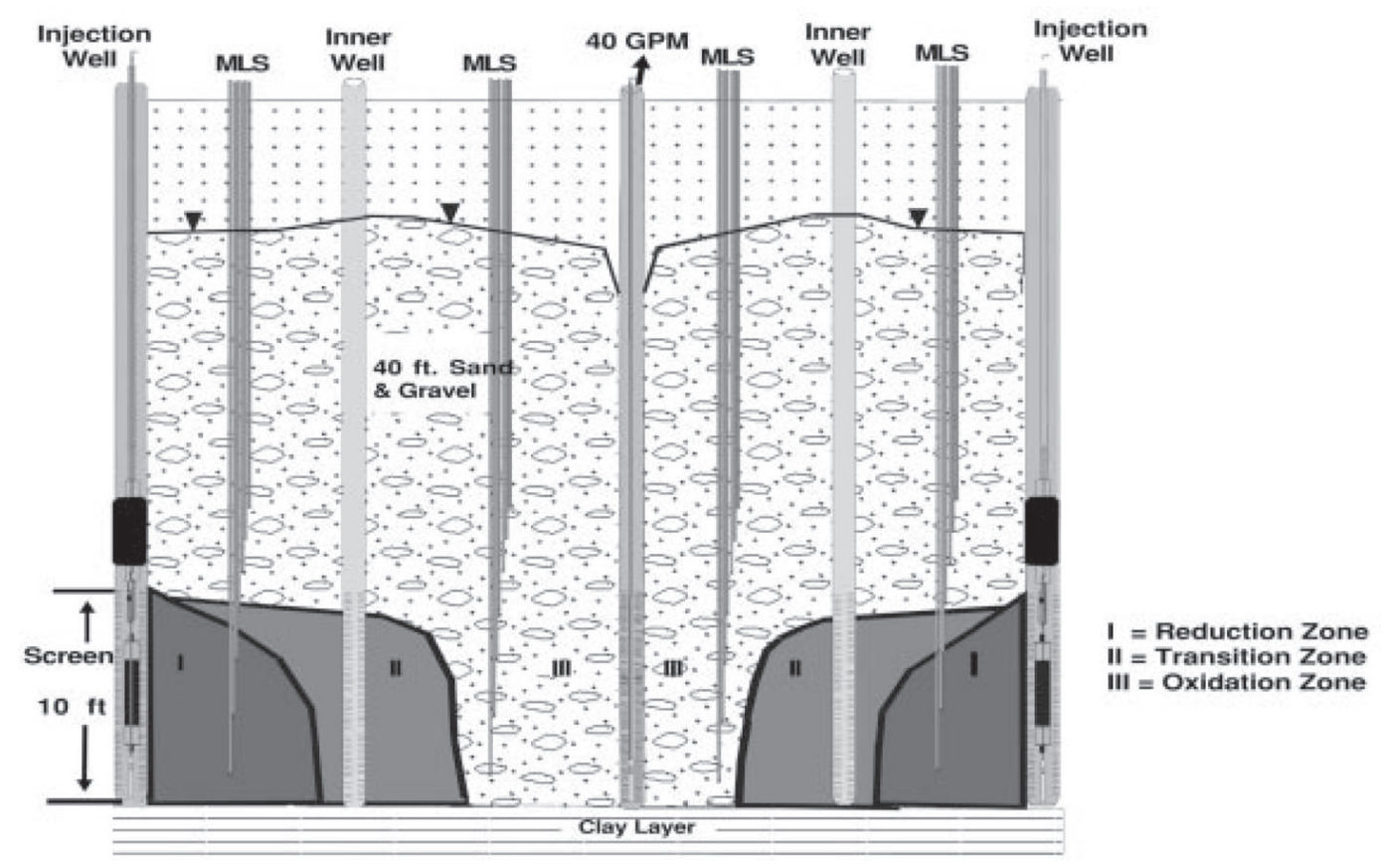

Exhibit 3. Geological cross-section showing injection apparatus used in pulse injection and vertical zones impacted at the site (10-foot injection). 
were installed in one quadrant of the daisy pattern to monitor the extent of denitrification. The multilevel samplers were constructed from 0.37 -inch outside diameter high density polyethylene (HDPE) tubing fastened with plastic bundle ties at appropriate depths to the piezometer. The piezometer was 1-inch diameter schedule 40 PVC pipe with a 2-foot slotted interval and capped at the bottom. The HDPE tubes were screened with a stainless steel screen port held in place with an HDPE ferrule at depths of $15,25,35,38,40,42,44,46$, and 48 feet below the ground surface. The MLS were installed with a hollow stem-auger (4-inch inside diameter) rig to depths of 48 feet from the ground surface. The saturated boreholes were allowed to slump as the augers were retrieved, and unsaturated zone boreholes were sealed with the bentonite slurry. The HDPE tubes of the MLS extend about 3 feet above the ground to facilitate sample collection with a peristaltic pump.

\section{Analytical Methods}

Each multilevel sampler was purged by removing three tube volumes prior to sample collection. Samples collected for anions and dissolved organic carbon (DOC) were stored on ice in the coolers for transport to the laboratory where they were stored in the refrigerators at $4{ }^{\circ} \mathrm{C}$. Anion samples were filtered through $0.2-\mu \mathrm{m}$ Whatman ${ }^{\circledR}$ membrane filters and were analyzed by ion-chromatography (APHA, 1998) using Dionex ${ }^{\otimes}$ DX-10o (Dionex Corporation, Sunnyvale, California, USA). DOC samples were collected in precombusted $40-\mathrm{ml}$ amber bottles containing $0.10 \mathrm{mg}$ of the preservative mercuric chloride $\left(\mathrm{HgCl}_{2}\right)$. DOC was determined by the wet oxidation method (APHA, 1998) using an Oceanography International ${ }^{\circledR}$ (OI) Total Organic Carbon Analyzer Model 700 (O.I. Corporation, College Station, Texas, USA).

Dissolved oxygen, (DO) bicarbonate-alkalinity, and turbidity were analyzed in the field. DO was measured by the iodometric method (modified Winkler) with azide modification (APHA, 1998) to eliminate nitrite interferences. Bicarbonate alkalinity was determined with a LaMotte ${ }^{\circledast}$ chemical titration kit (LaMotte Company, Chestertown, Maryland, USA). The $\mathrm{pH}$ of the water samples was determined in the field with a Fisher Accumet ${ }^{\circledR} \mathrm{pH} /$ specific ion meter Model 325 (Fisher Scientific, Pittsburgh, Pennsylvania, USA). Turbidity measurements were performed using a Hach ${ }^{\circledast}$ portable turbidimeter Model 2100P (Hach Chemical, Loveland, Colorado, USA), which was calibrated with turbidity standards prior to analysis. The results were reported in terms of Nephelometric Turbidity Units (NTU). Water level measurements in the injection well and the injection rate were recorded periodically to monitor the performance of the injection well.

\section{MODE OF OPERATIONS}

\section{Continuous Injection Mode}

In situ denitrification experiments were conducted with continuous injection of ethanol diluted with water containing $\sim 40 \mathrm{mg} \mathrm{NO} 3_{-} \mathrm{N} \mathrm{l}^{-1}$. In preliminary investigations oxidant injections were not performed in the inner perimeter wells, and carbon injections were limited to OW-6, an outer perimeter well (Exhibit 2) located in the southwest quadrant of the daisy circle. Water with $\sim 40 \mathrm{mg} \mathrm{NO} 3_{-}^{-} \mathrm{N} \mathrm{l}^{-1}$ was extracted from

Water level
measurements
in the injection
well and the
injection rate
were recorded
periodically
to monitor the
performance
of the injection
well.


two nonadjacent outer perimeter wells at a rate of 5 gallons per minute (GPM) each. This water was spiked with a premixed concentrate of ethanol and bromide by using a chemical feed diaphragm pump (Cole-Parmer, Vernon Hills, Illinois, USA) operated at a preset flow rate. The final injection solution contained $50 \mathrm{mg} \mathrm{Cl}^{-1}$ and 10 $\mathrm{mg} \mathrm{Brl}{ }^{-1}$. The solution was then injected into OW-6. Bromide is a conservative tracer used to monitor the movement of injectate. A decrease in the bromide concentration signals dilution by untreated groundwater containing elevated nitrate concentrations. The injection well was cleaned periodically by cycling a cleaning solution (mixture of 5 percent hydrogen peroxide and o.1 percent sodium hydroxide) with a device developed to circulate the cleaning solution under pressure (Exhibit 4). The device includes a 3.5-inch diameter top and bottom Baski ${ }^{\circledast}$ packers (Baski Inc., Denver, Colorado, USA), each equipped with the Grundfos submersible pump (Grundfos Pumps Corporation, Fresno, California). The packers are made of neoprene rubber and are inflated with any compressed gas from the ground surface. The inflated packers isolate the top portion of the well screen from the bottom part. To clean the well screen and the adjacent filter pack, water is pumped from the top portion of the screen to the surface where it is injected with the cleaning solution and returned to the bottom portion of the screen and vice versa. The pumping and injection hydraulics are designed to form a closed-loop flow pattern around the injection screens in order to clean an approximate 10-foot radius at and around the well screen.

\section{Pulse Injection Mode}

A pulsed injection system was developed to prevent the mixing of organic- $\mathrm{C}$ and nitrate, and thereby limit microbial growth in the vicinity of the injection well screen.

Exhibit 4. Tool developed to circulate cleaning solution in the vicinity of the injection well.

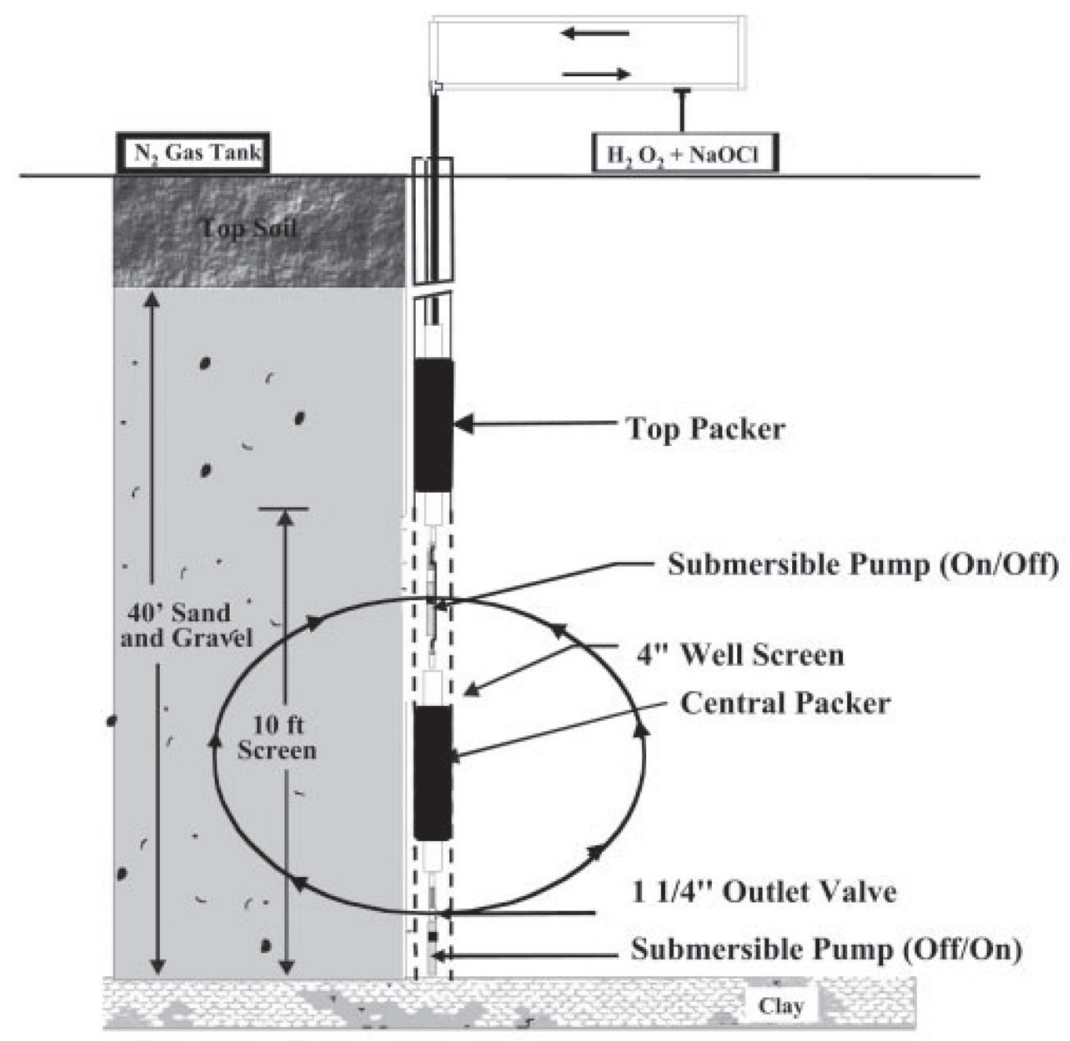


The approach is to alternately pulse nitrate (electron acceptor) contaminated water and ethanol (electron donor) solution into the well. This required a source of nitrate-free water from a specially installed bedrock well. For the full daisy well system, pulse injections were programmed using computer-controlled pumps and valving (Exhibit 2). Simultaneous injections were performed in a six-hour cycle in an opposite well pair and then moved to the next well pair. Thus each outer perimeter well received one six-hour injection in 24 hours. The following sequence of injection was performed during each six-hour cycle: (1) a 25-minute nitrate-free water pulse to wash the screen area, (2) a 55-minute pulse containing 500 mg-C l-1 ethanol, (3) a 25-minute pulse of nitrate-free water to wash the screen area, (4) a 4.25-hour $40 \mathrm{mg}$ $\mathrm{NO}_{3-} \mathrm{N}^{-1}$ pulse. Pressurized injections were maintained by inflating the top packer.

In the later experiments acetate replaced ethanol as an organic carbon source, and pulse injection occurred in eight outer perimeter wells. Silicon O-rings in the metering pump were replaced with corrosion resistant teflon O-rings for acetate injection. The pulsed injection sequence was the same as described above. The extraction well was operated at $40 \mathrm{GPM}$. On a weekly basis, $200 \mathrm{mg}^{-1}$ hydrogen peroxide was cyclically injected in each of the inner wells at a rate of 5 GPM for 30 minutes to oxidize residual carbon, nitrite, and microbial by-products before they reach the extraction well. The cleaning solution composition was modified to 5 percent $\mathrm{H}_{2} \mathrm{O}_{2}$ and 0.02 percent $\mathrm{NaOCl}$.

\section{RESULTS AND DISCUSSION}

\section{Continuous Injection Experiments}

A carbon nitrogen ratio of 1.25 exceeded the organic- $C$ requirements to reduce 40 mg $\mathrm{NO}_{3}-\mathrm{N} \mathrm{l}^{-1}$ to nitrogen. The extraction well was operated initially at a rate of 80 GPM, but 9o hours after the initiation of the injection, the extraction well was adjusted down to 40 GPM to allow sufficient residence time for bacteria to effectively utilize the substrate. Continuous amendment experiment results are shown in Exhibits 5 and 6 . During the first 50 hours of injection, only a slight decrease in nitrate concentration was observed (Exhibit 5). This is in sharp contrast to previous microcosm batch experiment results, showed that $40 \mathrm{mg} \mathrm{NO}_{3}-\mathrm{N} \mathrm{l}^{-1}$ was reduced completely within 40 hours of injection (Bates \& Spalding, 1998). Continuous input of the nutrient resulted in bacteria requiring additional time to adjust and acclimate to the nutritional changed environment (Exhibit 6). After 50 hours, the microbial population was developed in the denitrified zone and became metabolically active; nitrate reduction proceeded at a very fast rate. A significant decline in nitrate concentration was observed after 100 hours of operation in those depths where ethanol was injected. Maximum nitrate removal efficiency (100 percent) was achieved after 150 hours (Exhibit 5). This corresponds to treating approximately $2.2 \mathrm{~kg} \mathrm{NO}_{3^{-}} \mathrm{N} \mathrm{d}^{-1}$ in the denitrified zone (DNZ). As shown in Exhibit 6, bromide concentrations in the DNZ show minimal dilution by background high nitrate water. Also, nitrite, an intermediate product of denitrification, accumulates momentarily but was quickly reduced to below detection limit due to excess carbon present in the DNZ.

The performance of the injection well was monitored by noting decreased specific capacity (Exhibit 7), which is defined as the rate of injection per foot of head build-up (GPM $\left.\mathrm{ft}^{-1}\right)$. The specific capacity steadily declined after 144 hours until it
The extraction well was operated initially at a rate of 80 GPM, but 90 hours after the initiation of the injection, the extraction

well was adjusted down to 40 GPM to allow sufficient residence time for bacteria to effectively utilize the substrate. 


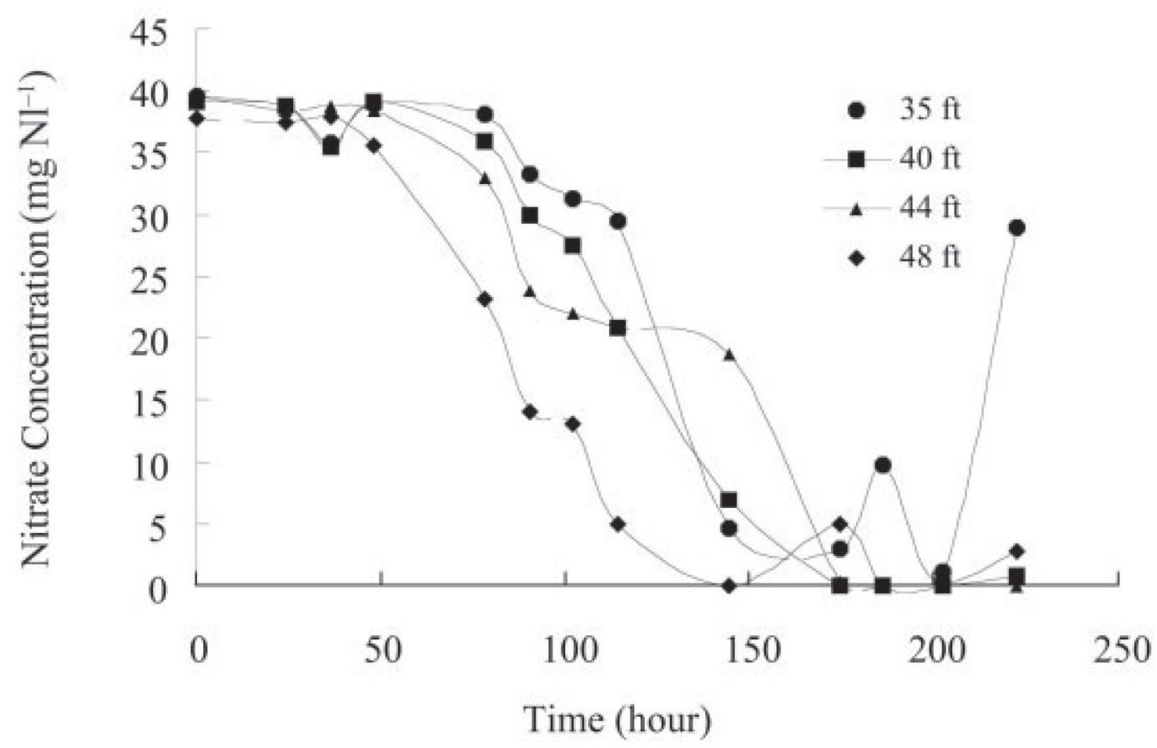

Exhibit 5. Nitrate reduction in ML-6 located in the DNZ during continuously amended experiment.

decreased to $1.5 \mathrm{GPM} \mathrm{ft}^{-1}$ and the injection well was inoperable after 240 hours. The bottom 15 feet of the injection pipe was covered with a thick coating of biomass. Presumably it was also coating the screen and clogging the well. Clogging mitigation techniques such as periodic cleaning of the screen and replacement of PVC screen with a copper screen failed to prevent the biofouling (Exhibit 8).

\section{Pulse Injection Experiments}

A preliminary pulsed injection experiment was conducted in one injection well, but later it expanded to four wells. In these experiments, nitrate was reduced to below detection levels in the impacted zones (Exhibit 9) with no detectable nitrite remaining after nine days of injection. In four well injections, $\sim 35$ percent nitrate reduction was observed in the extraction well (Exhibit 9). This met expectations for the treatment being applied to only the bottom quarter of the aquifer at four of eight injection wells. The maximum concentration of bromide observed in the extraction well was $1.96 \mathrm{mg} \mathrm{Br}-\mathrm{l}^{-1}$, which was about 25 percent of the bromide concentration $(8 \mathrm{mg}$ $\mathrm{Br}-\mathrm{l}^{-1}$ ) in the impacted zones (Exhibit 10). The substantial dilution of the bromide in the extraction well water supported the hypothesis that more than half of the water entering the capture zone of the extraction well was untreated. In the denitrified zones, DOC concentration increased substantially $\left(\sim 25 \mathrm{mg} \mathrm{C}^{-1}\right)$, which indicated that injected DOC exceeded the metabolic capacity of the microbes. The presence of an excess DOC after nitrate depletion resulted in undesirable sulfate reduction (Exhibit 10) and generated the rotten egg odor of hydrogen sulfide in samples collected from the DNZ. This indicated a need to micromanage residual carbon in the DNZ to prevent sulfate reduction.

Turbidity, which is an indirect measure of the amount of biomass present, increased more than tenfold in the extraction well samples (Exhibit 10). Although the injection wells were not clogged during three weeks of injection, partial clogging of the extraction well was observed. During routine maintenance, microbial 


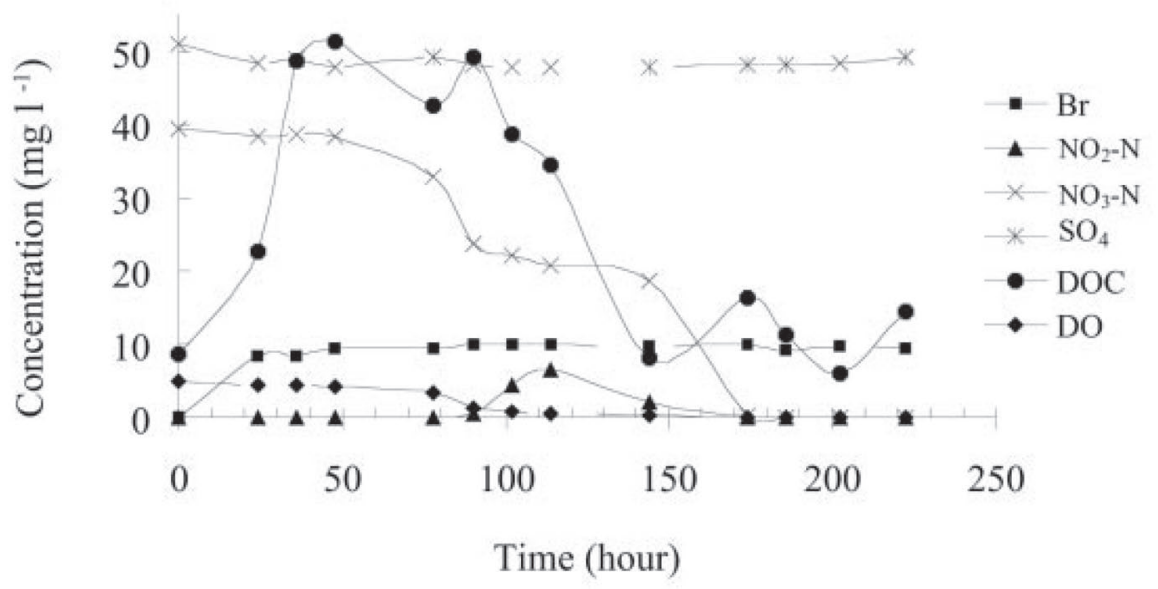

Exhibit 6. Analytes' concentration in ML-6-44 during continuously amended experiment.

growth on the injection line and appurtenances was also observed. These findings clearly indicated that ethanol promoted the growth of microbes, which secreted slime. Accumulation of such materials increase the risk of injection well and aquifer clogging. Other researchers who worked with ethanol encountered similar experiences (Ghose \& Bhadra, 1985; Peyton, 1996; Constantin \& Fick, 1997). The extraction well and injection line was cleaned with hydrogen peroxide and then disinfected with $\mathrm{NaOCl}$.

\section{Pulse Injection Experiment Using Acetate as a Carbon Source}

Ghose and Bhadra (1985) reported that acetate in comparison to ethanol was not easily fermented, did not participate in futile side reaction, and created less biomass. Mateju et al. (1992) and Constantin and Fick (1997) reported that during denitrifica-

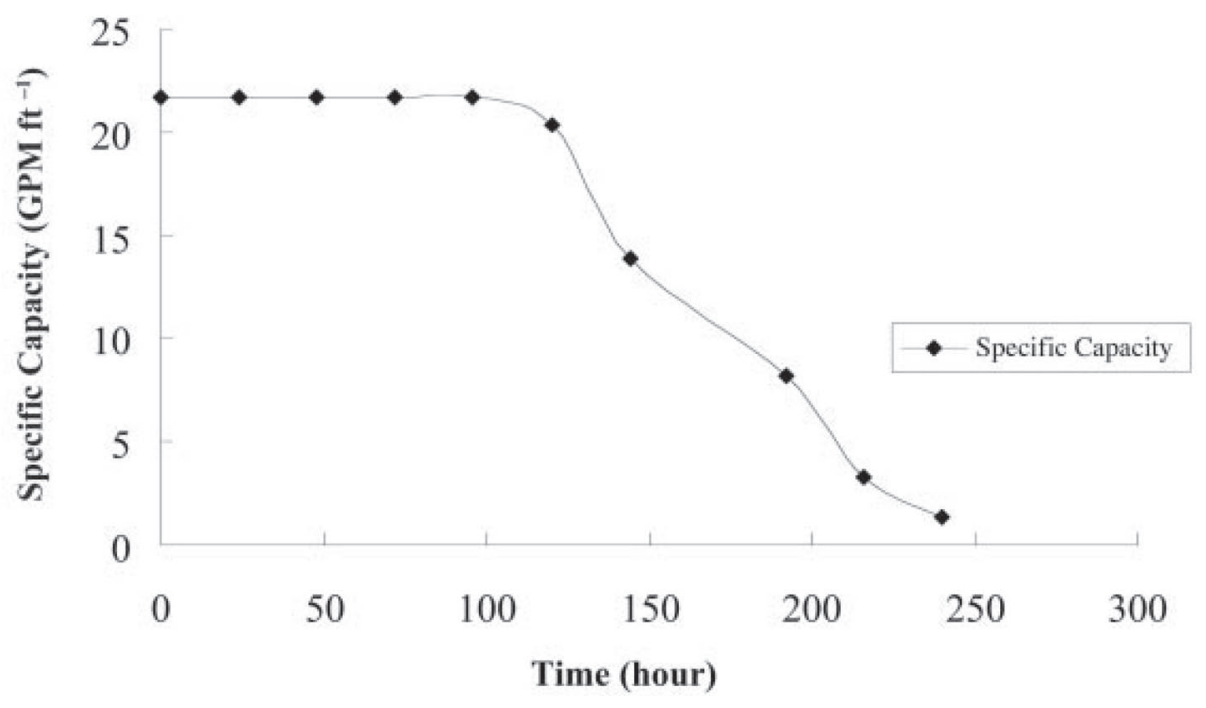

Exhibit 7. Injection well (OW-6) clogging during continuously amended experiment. 


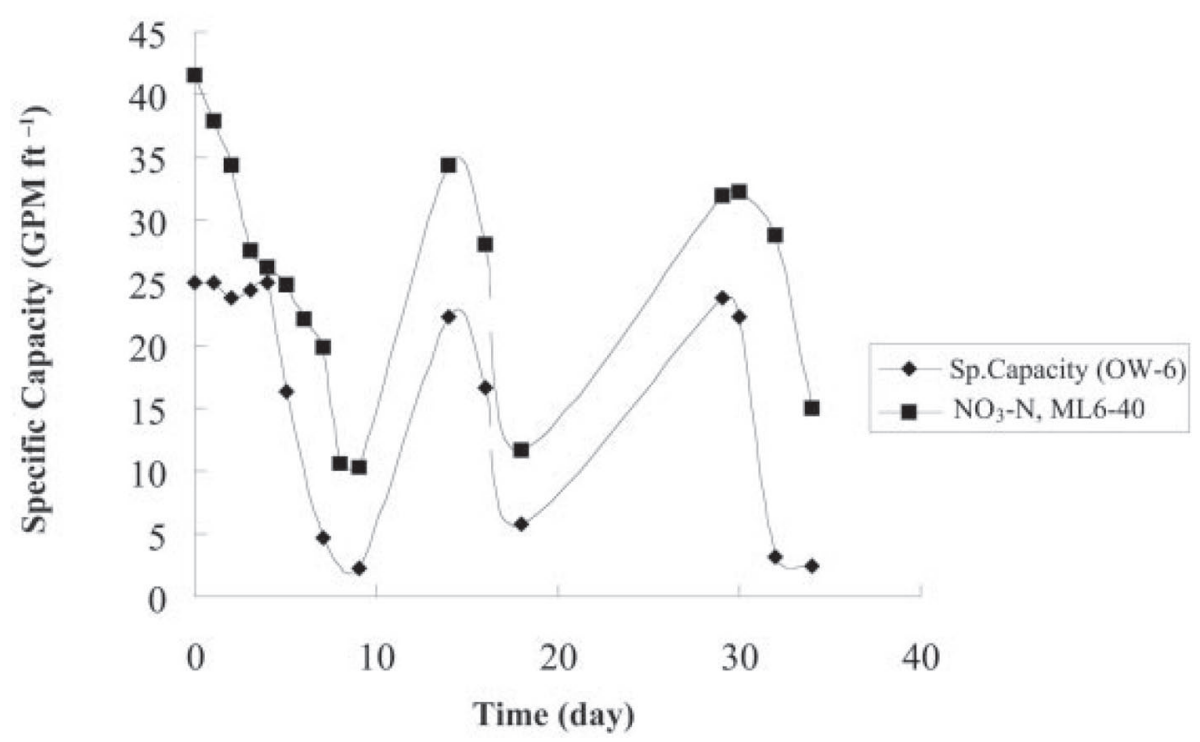

Exhibit 8. Decrease in the nitrate concentration and specific capacity of the injection well (OW-6) during continuous ethanol amendment with periodic cleaning of the injection well.

tion, acetic acid caused three times less bacterial growth than ethanol. In order to reduce biomass, acetate was substituted for ethanol in the remaining experiments.

A three-month study was conducted using the previously described automated injection sequence with the only modification being the substitution of 350 parts per million (ppm) acetate-C for 500 ppm ethanol-C. Exhibit 11 shows that denitrification occurred in the entire perimeter area of the daisy circle and throughout the 10-foot screen section of the aquifer. Nitrate was reduced below the MCL in the DNZ. Nitrate concentration in the extraction well water was reduced to $\sim 21 \mathrm{mg} \mathrm{l}^{-1}$ (Exhibit 12). This represents 45 percent nitrate removal efficiency, which is much better

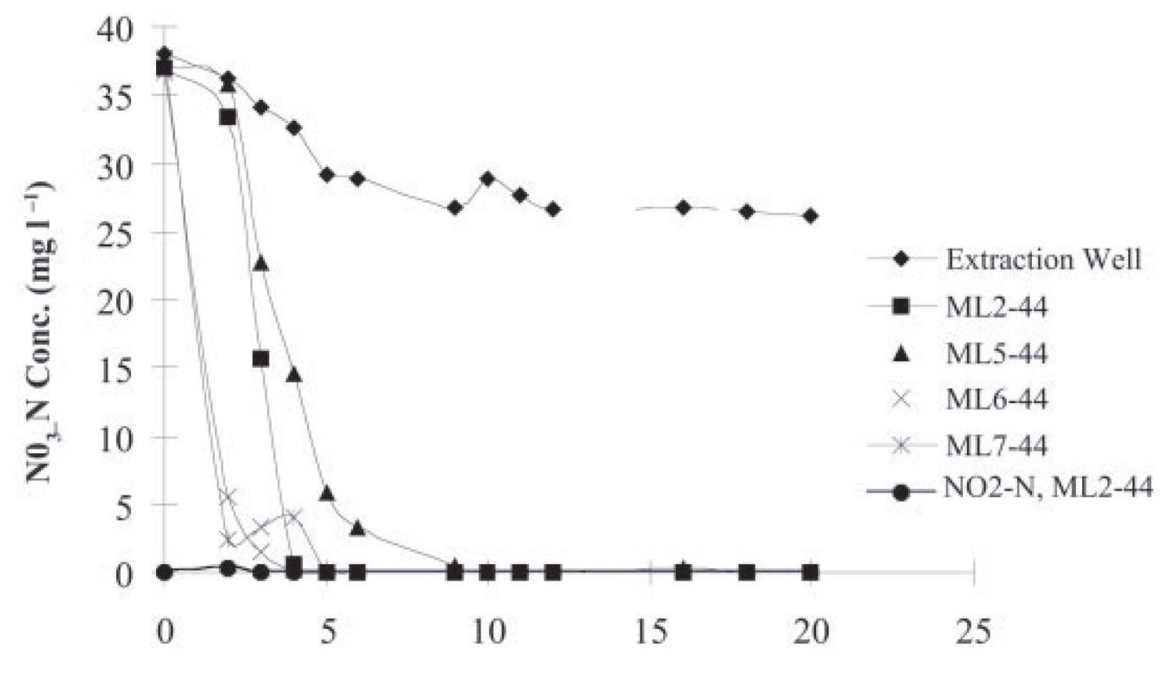

Time (day)

Exhibit 9. Nitrate profile in the DNZ at depth 44 feet during four-well pulse injection of ethanol. 

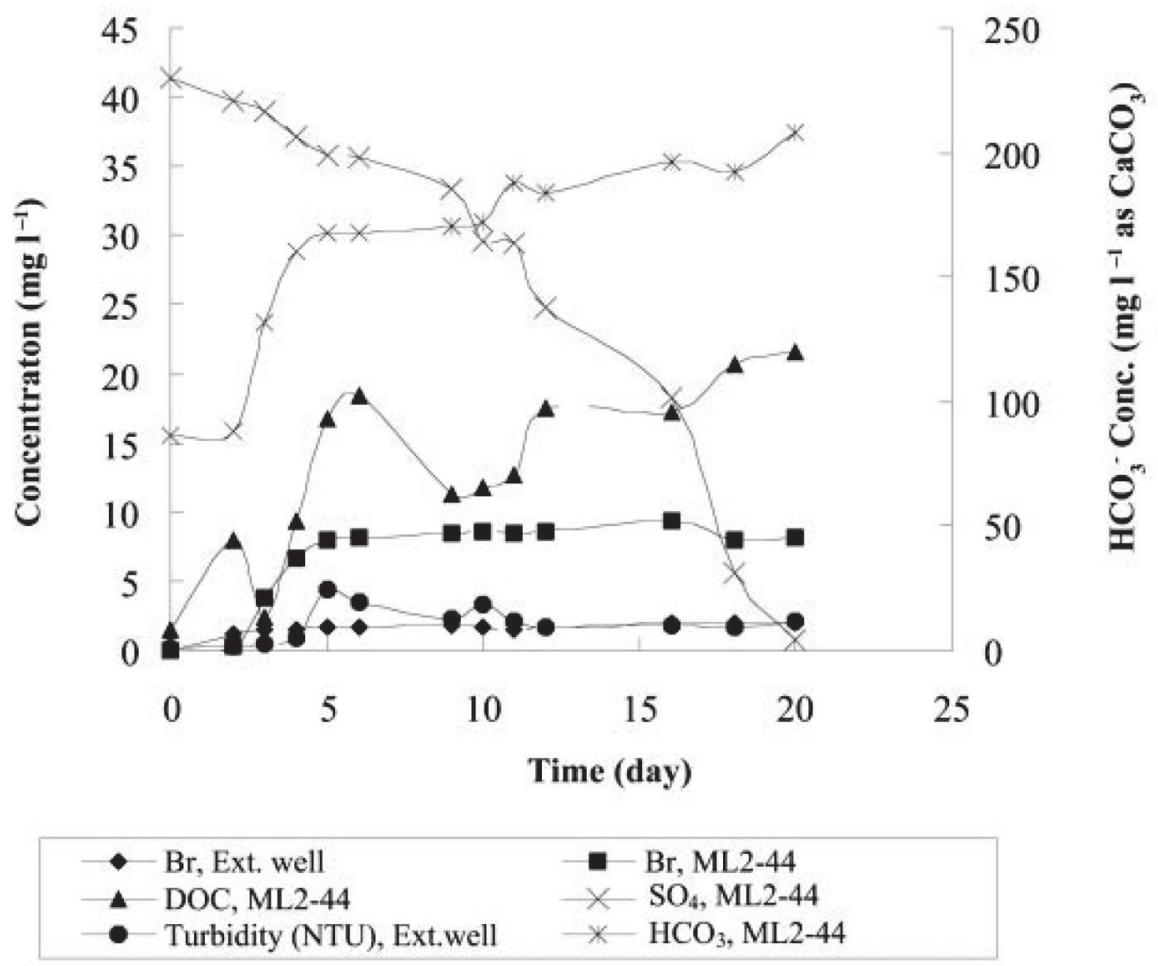

Exhibit 10. Analytes concentration in the DNZ during four-well pulse injection of ethanol.

than demonstrated previously in the four-well injection experiment, but the residual $\mathrm{NO}_{3^{-}} \mathrm{N}$ still exceeded the MCL. By using eight injection wells, the full daisy circle was denitrified; however, the downward movement of untreated water above the

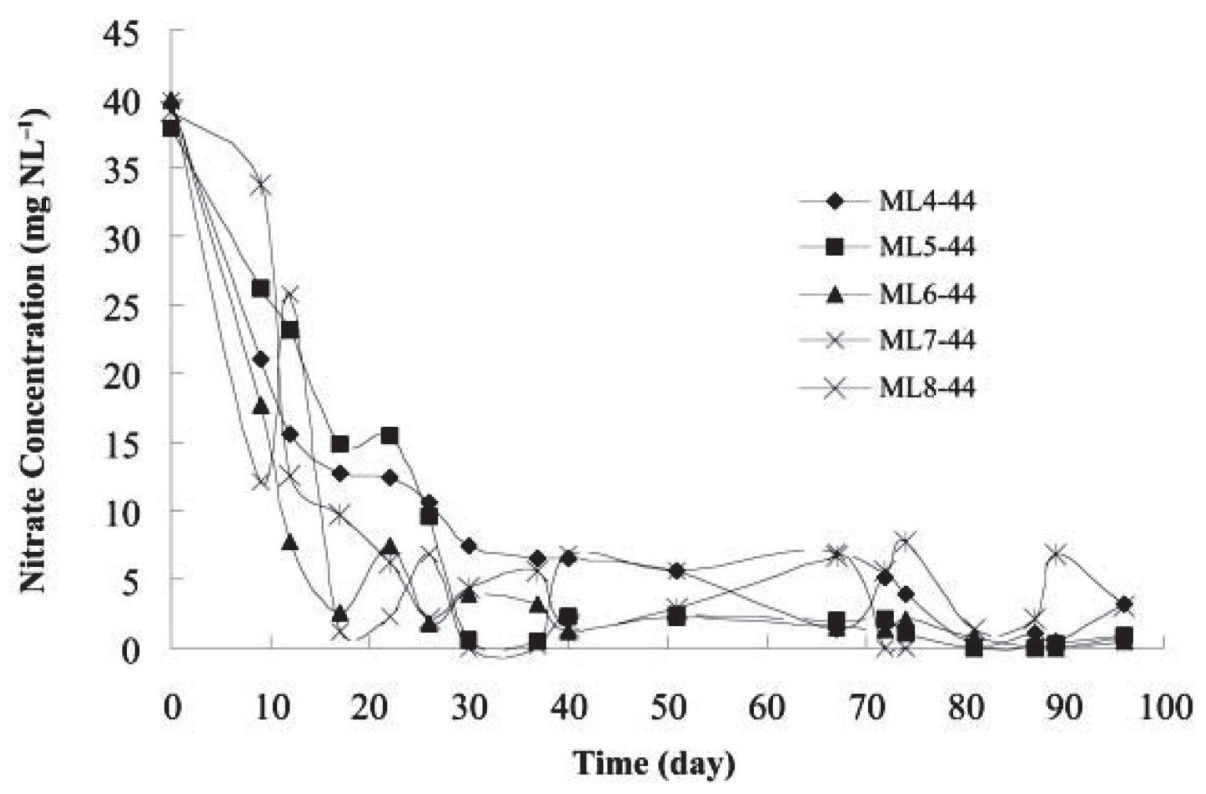

Exhibit 11. Nitrate profile in the DNZ located in southwest quadrant of the daisy circle during the eight-well pulse injection of acetate. 


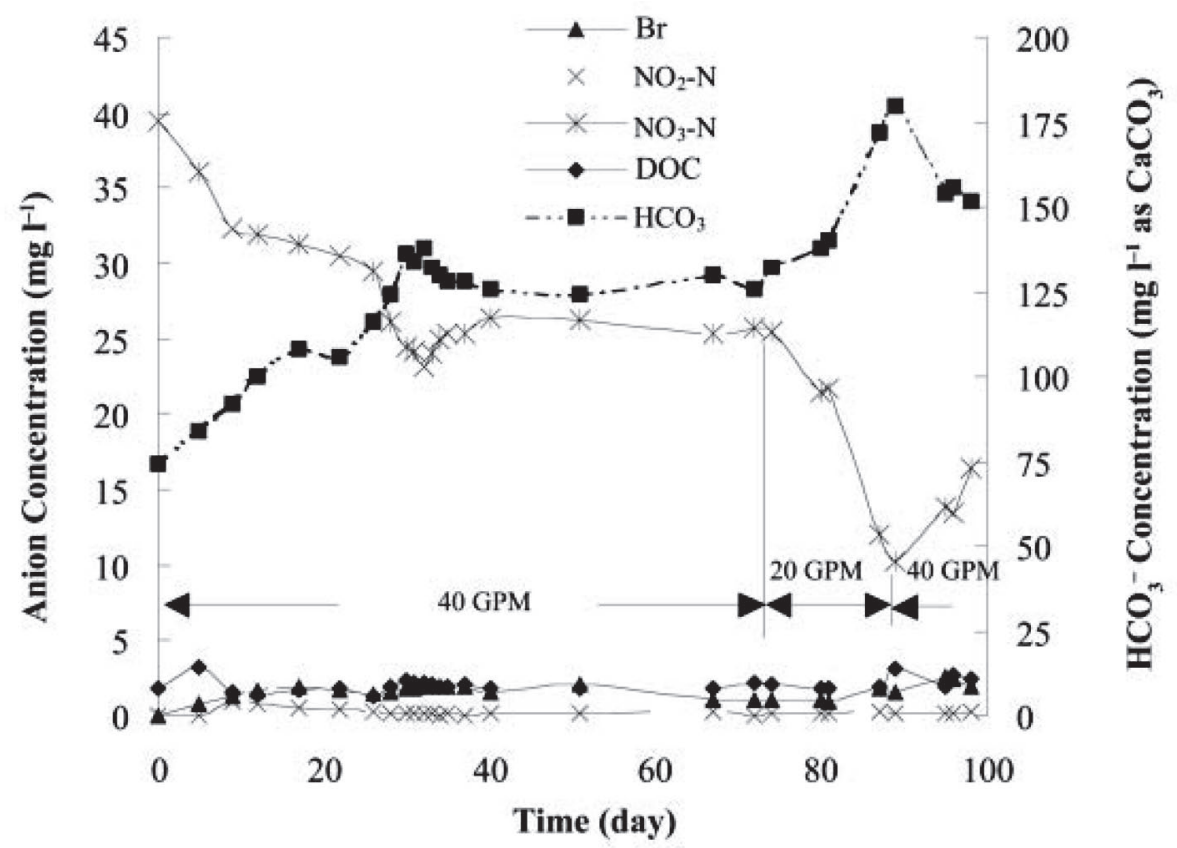

Exhibit 12. Extraction well analyte concentrations during the eight-well pulse injection of acetate.

screen resulted in extraction well nitrate concentration higher than that observed in the DNZ. Bromide dilution in extraction well samples confirmed that untreated water above the screen zone entered the capture zones and contributed to a higher nitrate concentration than the DNZ. Cross channeling of the untreated water appears to have been an artifact of the design of the partially penetrating daisy well system. To test this hypothesis, the extraction well pumping rate was lowered 50 percent on

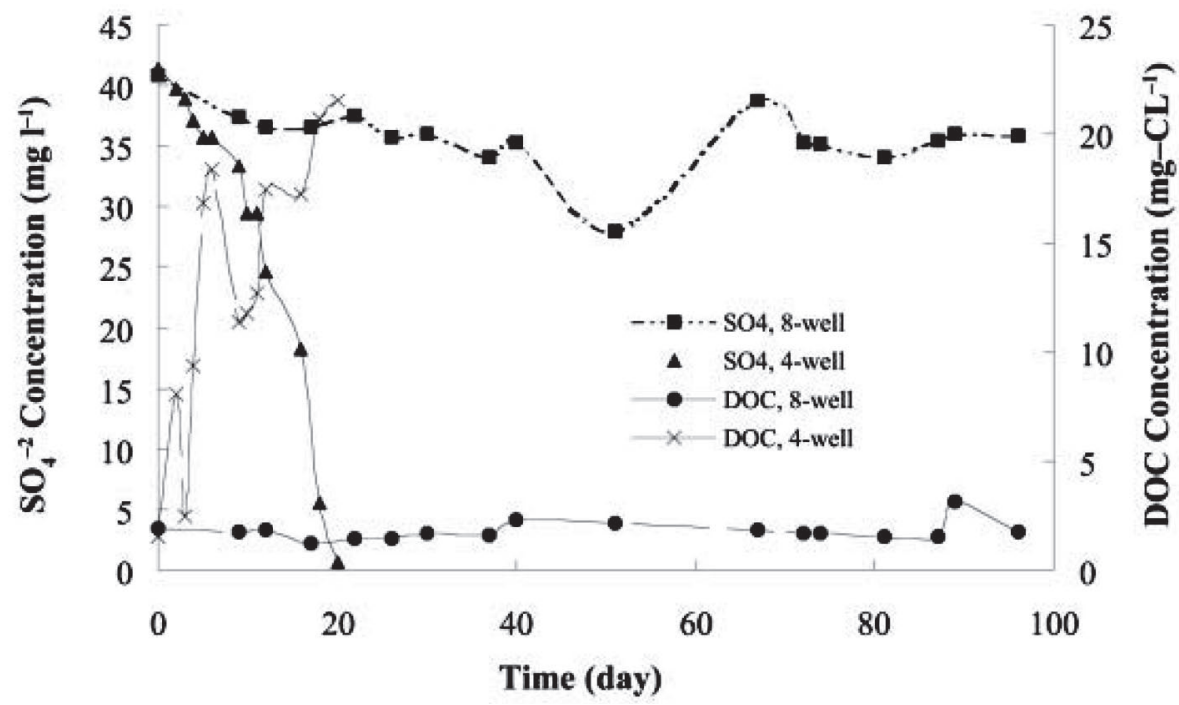

Exhibit 13. Observed sulfate and DOC concentrations at ML2-44 ft during eight-well pulse injection of acetate and four-well pulse injection of ethanol. 


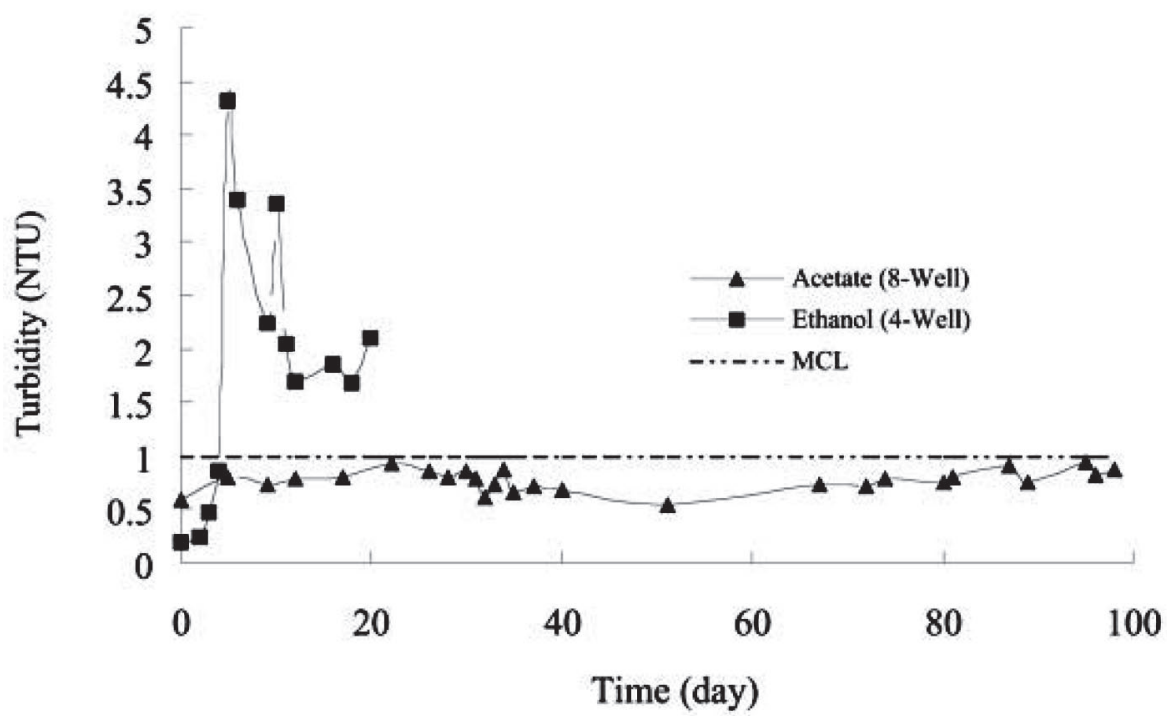

Exhibit 14. Comparison of the turbidity increase during pulse injection experiments using ethanol and acetate as a carbon source.

the 8oth day for a one-week period (Exhibit 12). During this seven-day period, the cross channeling effect was greatly reduced and a significant improvement in the ability of the extraction well to capture denitrified water occurred. Nitrate-N concentrations were reduced to $13 \mathrm{mg} \mathrm{N} \mathrm{I}^{-1}$. This suggested a need to either operate the extraction well at a rate that maximizes the capture of the denitrified water, or to denitrify the entire depth of the primary aquifer by installing fully penetrating wells.

During the experiment, residual DOC was extensively monitored and acetate injectate concentration was adjusted to maintain a small amount of nitrate residual in the DNZ. This promoted denitrification without sulfate reduction (Exhibit 13). The

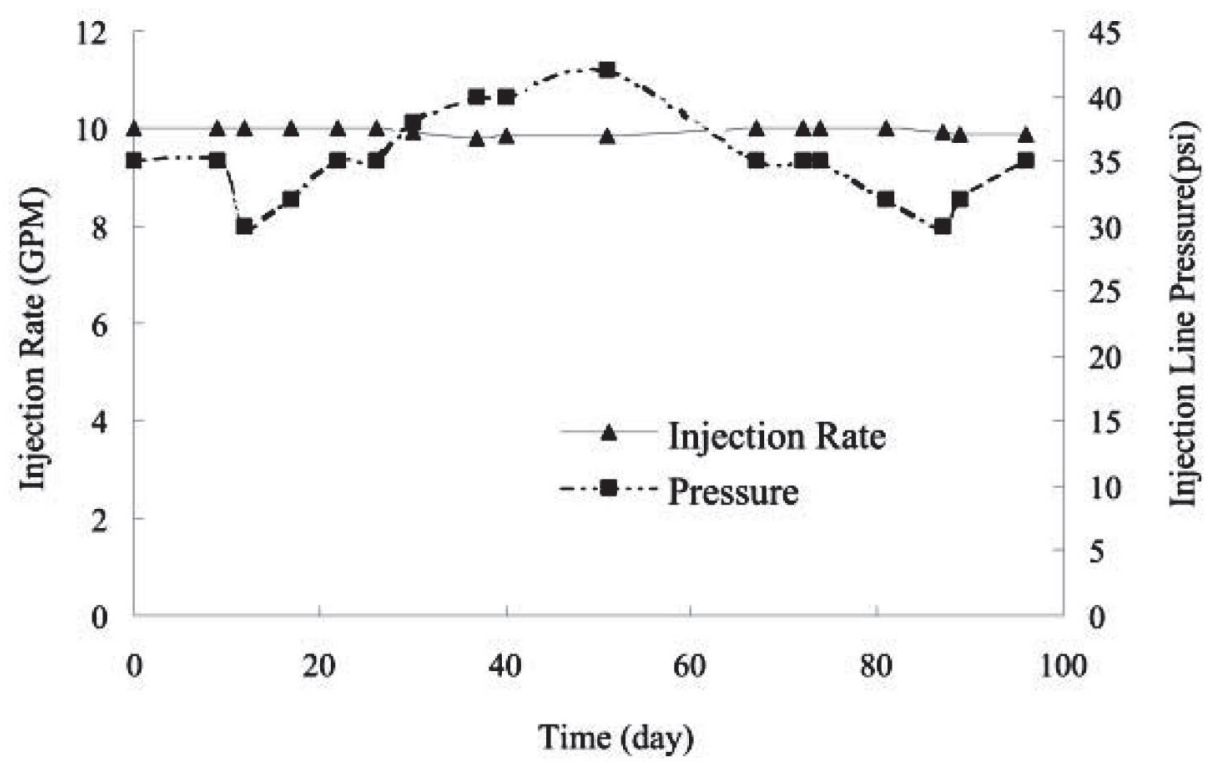

Exhibit 15. Injection well performance during the eight-well pulse injection of acetate. 


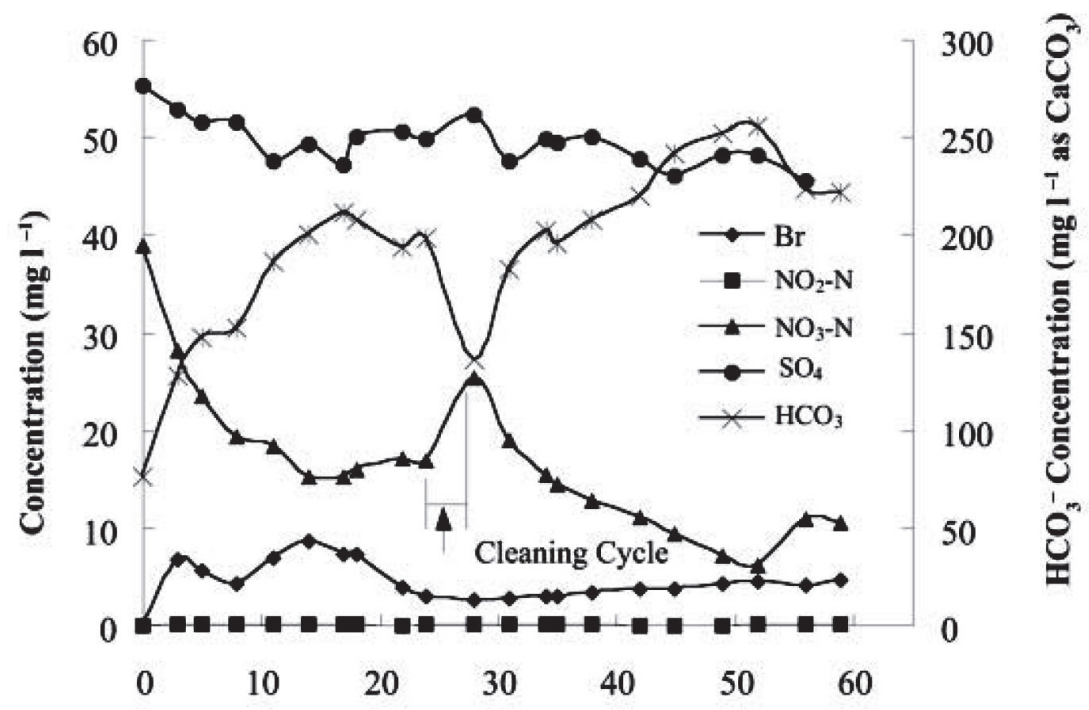

Time (day)

Exhibit 16. Extraction well analytes concentration during eight-well (20-foot injection screen) pulse injection of acetate.

turbidity increase with acetate was minimized in comparison to ethanol in the DNZ (Exhibit 14). Injection wells remained free from clogging during the three-month operation. The injection rate remained steady with injection pressures varying in the range of 35 to 45 pounds per square inch (psi) (Exhibit 15). The injection line, appurtenances, and the injection wells were routinely cleaned every month.

In the final denitrification experiment, the efficacy of nitrate reduction was increased by expanding the impacted zones by vertically lengthening the injection well screens from 10 feet to 20 feet and increasing the injection rate to 20 GPM. The 10-foot screened extraction well was pumped at 40 GPM. To improve the quality of denitrified water entering the capture zone of the extraction well, $200 \mathrm{mg} \mathrm{l}^{-1}$ hydrogen peroxide was cyclically injected on a weekly basis at a rate of 5 GPM for 30 minutes in each inner well. During a two-month study, the nitrate-N concentration in the extraction well was reduced from $39 \mathrm{mg} \mathrm{l}^{-1}$ to $11 \mathrm{mg} \mathrm{l}^{-1}$ (Exhibit 16). The vertical extent of denitrified water in the capture zones of the extraction well was increased by denitrifying the bottom half of the aquifer, which formed a buffer between the well screen and overlying non-treated high-nitrate water. This decreased the probability of high nitrate water from above the screen entering the capture zones of the extraction well. As a result 72 percent denitrified water was captured. For a one-week period (day 45 to day 54 in Exhibit 16) the nitrate-N concentration fell below the MCL; however, at the end of the study nitrate-N concentration rose slightly above $10 \mathrm{mg} \mathrm{l}^{-1}$. Bicarbonates are produced when ethanol is oxidized during denitrification. Concentration of bicarbonates in the extraction well increased from $75 \mathrm{mg} \mathrm{l}^{-1}$ as $\mathrm{CaCO}_{3}$ to a maximum concentration of $250 \mathrm{mg} \mathrm{l}^{-1}$ as $\mathrm{CaCO}_{3}$ (Exhibit16). This increase in bicarbonate concentration could increase slightly the hardness of the extraction well water. The maximum residual DOC concentration observed in the extraction well samples was $6.0 \mathrm{mg}-\mathrm{C}^{-1}$ while dissolved oxygen decreased to $1.5 \mathrm{mg}$ $1^{-1}$ (Exhibit 17). This indicated that acetate was almost completely consumed dur- 


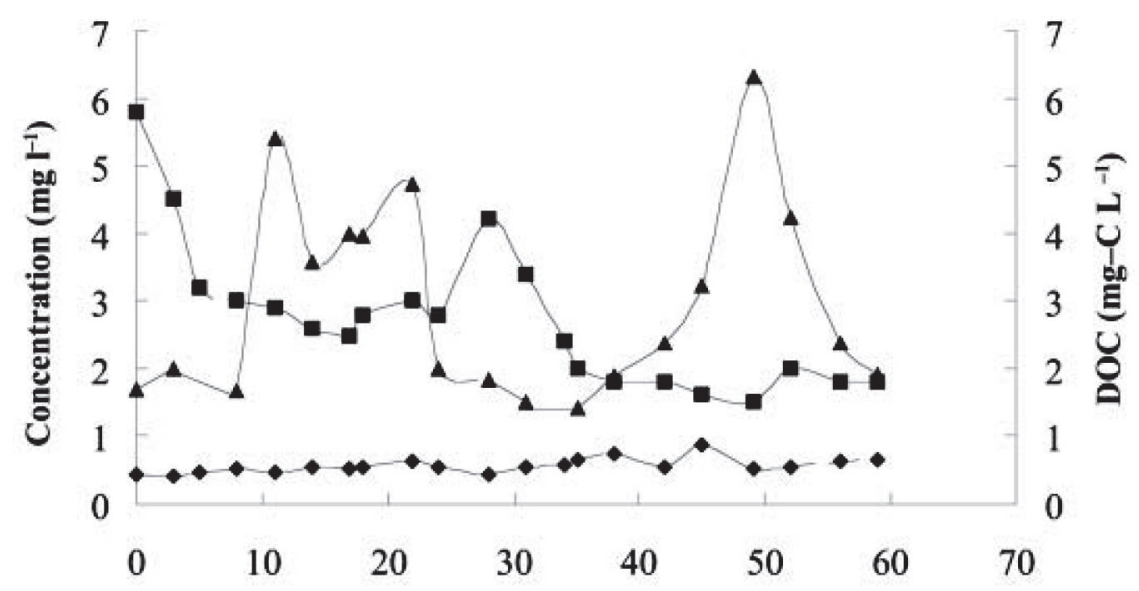

Time (day)

- Turbidity (NTU) - DO $\triangle$ DOC

Exhibit 17. Extraction well analytes concentration during eight-well (20 ft injection screen) pulse injection of acetate.

ing deoxygenation and denitrification reactions. During the cleaning cycle (day 25 in Exhibits 16 and 17), due to rapid decrease in the DOC concentrations, nitrate and dissolved oxygen concentration rose temporarily but decreased almost immediately when acetate injection resumed. This shows that the cleaning cycle did not affect the performance of the denitrification process. The turbidity in the extraction well water remained below 1.0 turbidity (NTU). These results indicated that the daisy well system successfully denitrified high-nitrate groundwater without creating clogging and water quality problems. In future experiments bacterial counts and trihalomethanes will be measured to determine the potability of extraction well water.

\section{CONCLUSIONS}

Continuous and pulse addition of organic substrate successfully reduced nitrate concentrations to below the detection limit in the denitrified zones within ten days. This rapid reduction of nitrate demonstrated the potential of in situ bioremediation to treat elevated nitrate concentrations. Results of several experiments indicated that acetate performed better than ethanol because less biomass was produced in the aquifer. Pulsed injection of acetate and periodic cleaning of injection wells and lines effectively controlled clogging. Hydrogen peroxide injections in the inner wells improved the quality of the extraction well water. A $72 \%$ nitrate reduction was observed in the extraction well water. This reduction would be sufficient for most municipalities to easily bring nitrate levels to compliance. The use of this in situ treatment is also considerably less costly in terms of capital cost and operation and maintenance cost. The method will next be tested in a municipal well field where its potential to deliver potable water will be assessed.

Acknowledgments - This project was funded by the Bureau of Reclamation and Central Platte Natural Resource District. We thank Larry Cast and Mike Kube of the Bureau and Mark Burbach and 
Jeff Toavs for their field assistance. We also thank Bart Faris, team leader of the ITRC In Situ Bioremediation team, for his moral support and guidance. We express our gratitude to Mr. and Mrs. John Jefferson for volunteering their property for the project. This manuscript has been assigned Journal Ser. No. 13951, Agricultural Research Division, University of Nebraska.

\section{REFERENCES}

APHA. (1998). Standard methods for the examination of water and wastewater (20th ed.). Washington, DC: American Public Health Association.

Bates, H. K., \& Spalding, R. F. (1998). Aquifer denitrification as interpreted from in-situ microcosm experiments. Journal of Environmental Quality, 27, 174-182.

Bouwer, E. J., \& Crowe, P. B. (1982). Biological process in drinking water treatment. Journal of American Water Works Association, 80(9), 82-93.

Braester, C., \& Martinell, R. (1988). The Vyredox and Nitredox method of in-situ treatment of groundwater. Water Science and Technology, 20, 149-163.

Chalupa A. (1985, October 22-24). La Denitrification Artificielle des Eaux de Nappe. Paper presented at the conference Nitrates Dans les Eaux, Paris.

Constantin, H., \& Fick, M. (1997). Influence of C-source on the denitrification rate of a highnitrate concentrated industrial wastewater. Water Research, 31 (3), 583-589.

Ghose, T. K., \& Bhadra, A. (1985). Acetic acid. In Comprehensive biotechnology, The practice of biotechnology: Current commodity products (Vol. 3, pp. 701-729). London, UK: Pergamon Press.

Hammon, M., \& Fustec, E. (1991). Laboratory and field study of an in-situ groundwater denitrification reactor. Research Journal WPCF, 8(4/5), 942-949.

Interstate Technology and Regulatory Cooperation Work Group. (2000). Technology overview-Emerging technologies for enhanced in situ biodenitrification (EISBD) of nitratecontaminated groundwater. Available: www.itrcweb.org

Janda, V., Rudvsky, J., Wanner, J., \& Marha, K. (1988). In-situ denitrification of drinking water. Water Science and Technology, 20, 215-219.

Khan, I. A. (2000). In-situ aquifer denitrification using a daisy well system. Ph.D. Thesis. University of Nebraska, Lincoln, NE.

Kruithof, J. C., Paassen, van J. A. M., Hijnen, W. A. M., Dierx, H. A. L., \& Bennekom, van C. A. (1985, October 22-24). Experiences with nitrate in the eastern Netherlands. Nitrates dans les Eaux. Unpublished conference proceedings, Paris.

Mateju, V., Cizinska, S., Krejci, J., \& Janock, T. (1992). Biological water denitrification-A review. Enzyme Microb. Technol., 14, 170-183.

McDonald, M. G., \& Harbaugh, A. W. (1988). A modular three-dimensional finite-difference groundwater flow model. Techniques of Water Resources Investigation 06-A 1, USGS.

McMahon, P. B., Dennehy, K. F., \& Bruce, B. W. (1998). In-situ bioremediation of nitrate contaminated groundwater-A pilot test, Julesburg, Colorado, 1996-1997. USGS Water Resources Investigations Report, 98-4046.

Mercado, A. M., Libhaber, M., \& Soares, M. I. M. (1988). In-situ biological groundwater denitrification: Concepts and preliminary field tests. Water Science and Technology, 20, 197-209.

Moench, A. F. (1993). Computation of type curves for flow to partially penetrating wells in water-table aquifers. Groundwater, 31 (6), 966-971.

Nuttall, H. E. (1997). Restoring New Mexico's groundwater using biodenitrification. New Mexico Journal of Science, 54-73.

Peyton, B. M. (1996). Improved biomass distribution using pulsed injections of electron donor and acceptor. Water Research, 30(3), 756-758.

Pollock, D. W. (1994). User guide for Modpath/Modpath-Plot, Version 3: A particle tracking post-processing package for Modflow, the USGS finite-difference groundwater model. U.S. Geological Survey, Open File Report 94-464, Reston, VA. 
Rogalla, F., de Larminat, G., Coutelle, J., \& Godart, H. (1991). Experience with nitrate removal methods from drinking water. In I. Bogardi \& R. D. Kuzelka (Eds.). Nitrate contamination: Exposure, consequences, and control, NATO, ASI Series G, Vol. 30. Springer-Verlag Publisher.

Semprini, L., Roberts, P. V., Hopkins, G. D., \& McCarty, P. L. (1988). Field evaluation of aquifer restoration by enhanced biotransformation. Proceedings of International Conference on Physiochemical and Biological Detoxification of Hazardous Wastes, Technomic, Lancaster, PA.

Shouche, M. S., Petersen, J. N., \& Skeen, R. S. (1993). Use of a mathematical model for prediction of optimum feeding strategies for in-situ bioremediation. Applied Biochemistry and Biotechnology, 39/40, 763-779.

Spalding, R. F., \& Exner, M. E. (1993). Occurrence of nitrate in groundwater: A review. Journal Environmental Quality, 22, 392-402.

Spalding, R. F., Gormly, J. R., Curtis, B. H., \& Exner, M. E. (1978). Nonpoint nitrate contamination of groundwater in Merrick County Nebraska. Groundwater, 16, 86-95.

Walton, G. (1951). Survey of literature relating to infant methemoglobinemia due to nitrate contaminated water. American Journal Public Health, 41, 986.

Weyer, P. J., Cerhan, J. R., Kross, B. C., Hallberg, G. R., Kantamneni, J., Brever, G., et al. (2001). Municipal drinking water nitrate level and cancer risk in older women: The lowa women's health study. Journal Epidemiology, 11 (3), 327-338.

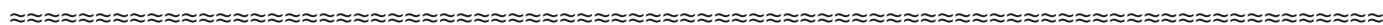

Imtiyaz A. Khan is a research associate in the Department of Agronomy and Horticulture at the University of Nebraska-Lincoln. He has a M.S. degree in Environmental Engineering and a Ph.D. in Agronomy and Horticulture (Soil and Water Sciences). His interests include development of innovative and economic solutions for nitrogen contamination.

Roy F. Spalding is a professor in the Department of Agronomy and Horticulture at the University of Nebraska-Lincoln. He has published over 100 journal articles, reports, and peerreviewed book chapters. His research interests include: applications of amended in situ biodenitrification, and development and application of economical alternatives to commonly used treatment technologies at Superfund sites. 